\title{
Wet Season Variations of some Physicochemical Parameters of the Brackish Water farm, Buguma, Niger Delta, Nigeria
}

\section{Owhonda KN*}

African Regional Aquaculture Centre/Nigerian Institute for Oceanography and Marine Research, Buguma, P.M.B 5122, Port Harcourt, Nigeria

\begin{abstract}
Some physicochemical parameters of Nigerian Institute for Oceanography and Marine Research/African Regional Aquaculture Centre (NIOMR/ARAC) brackish water fish farm; Buguma; Rivers State; Nigeria were monitored twice each month from April to October in 2011 and 2012; covering wet season for both years in the region. The result obtained indicates that for $2011 \mathrm{pH}$; ammonia-nitrogen; nitrite-nitrogen; nitrate-nitrogen; alkalinity; carbon

(iv) oxide; salinity; dissolved oxygen and temperature ranges were between 6.5-7; 0-0.1 ppm; 0.25-0.25 ppm; 40-80 ppm; 5-10 ppm; 9-20 ppt; 3.8-6 ppm and 26-31oC respectively while for $2012 \mathrm{pH}$; ammonia-nitrogen; nitritenitrogen; nitrate-nitrogen; alkalinity; carbon (iv) oxide; salinity; dissolved oxygen and temperature ranges were between 6.5-7; 0-0.1 ppm; 0.05-0.05 ppm; 0.05-0.25 ppm; 40-80 ppm; 5-10 ppm; 9-20 ppm; 3.8-5.6 ppm; 26-31oC respectively. There were no significant differences $(p>0.05)$ in all parameters for both years and the values measured were within tolerable limits for optimum aquaculture.
\end{abstract}

Keywords: Physicochemical parameters; Ph; Ammonia-Nitrogen; Nitrite-Nitrogen; Nitrate-Nitrogen; Alkalinity; Carbon(Iv)oxide; Salinity; Dissolved Oxygen and temperature ranges; Wet season; Brackish water; Fishpond

\section{Introduction}

Water quality parameter reflects the water composition as affected by both natural anthropogenic activities expressed in terms of measurable quantities. Knowledge of hydrological conditions of water body helps assess its productivity as well as a better understanding of the population and life cycle of the fish community [1-3]. Effective monitoring of hydrological variables of water bodies has led to the application of manipulations strategies to maximize fish production [4]. This is not surprising because physicochemical characteristics of the aquatic environment directly influence the life inhabiting it [5]. The study of different physicochemical parameters is very important for understanding the metabolic events in aquatic ecosystem. The monitoring of physicochemical variables is centered on determining optimal (Figure 1); sub lethal and lethal values essential for optimum fish production in brackish water ponds [6]. The parameters influence each other and govern the distribution and abundance of flora and fauna [7]. Although few studies have been carried out on the physicochemical parameters of important rivers in the Niger Delta by Dublin-Green [8] on the Bonny River; Yoloye [9] on Andoni River; Yakubu et al. [10] on lower River Nun and Erondu and Chinda [11] on lower New Calabar River; according to Francis et al. [12] monitoring brackish water environment is necessary due to its constant dynamic nature. Although Owhonda et al. [6] carried out seasonal variation studies for 2005 this work was carried out to compare the variations in 2011 and 2012 Table 1. Since we know that anthropogenic activities also introduce pollution to water bodies and many ponds get their water supply from other larger water bodies it is also necessary to constantly monitor the physicochemical parameters of ponds (Figure 2). Hydrological condition of water affects aquaculture activities; fish productivity and species composition of aqua fauna; eutrophication and the overall loss of biodiversity that results in degradation of pond ecosystem [13].

The major changes associated with electrochemical properties of pond water are reflected by the $\mathrm{pH}$ and electrical conductivity (Figure 3 ).
Neutral to slightly alkaline $\mathrm{pH}$ ranges for water are considered to be congenial for aquatic production owing to greater availability of most of nutrient elements and also due to increased biological activities under this $\mathrm{pH}$ range [13]. Bicarbonate $\left(\mathrm{HCO}_{3}^{-}\right)$and carbonate $\left(\mathrm{CO}_{3}^{2-}\right)$ constitute major anions in fish pond ecosystem and provide $\mathrm{CO}_{2}$ in water which are required for photosynthesis. Seasonal variation of water quality variables are also indications of the changes to which aquatic organisms must adapt if they are to survive. According to Nwadukwe and Onuoha [14]; temperature; $\mathrm{pH}$; salinity; dissolved oxygen and the level of metabolic wastes like ammonia; sulphide and nitrite nitrogen indicate the quality of the pond and in addition with other factors; are paramount features affecting the growth and health of fish (Figure 4). The Nigerian Institute for Oceanography and Marine Research/African

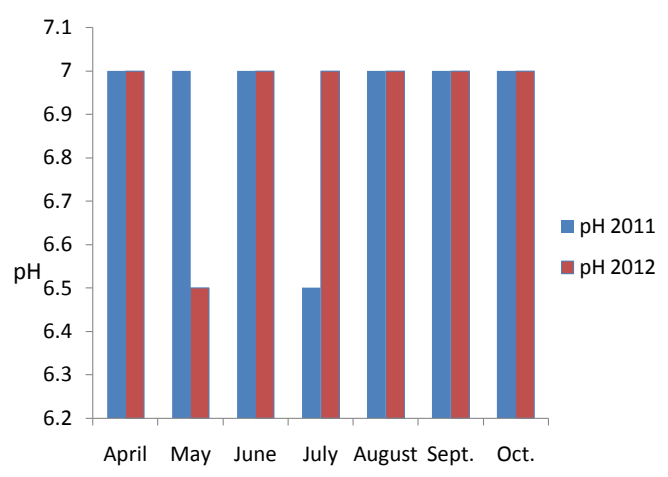

Figure 1: $\mathrm{pH}$ variation for 2011 and 2012

${ }^{*}$ Corresponding author: Owhonda KN, African Regional Aquaculture Centre/Nigerian Institute for Oceanography and Marine Research, Buguma, P.M.B 5122, Port Harcourt, Nigeria, E-mail: kingsleyndubuisiowhonda@gmail.com

Received April 17, 2015; Accepted May 11, 2015; Published June 30, 2015

Citation: Owhonda KN (2015) Wet Season Variations of some Physicochemical Parameters of the Brackish Water farm, Buguma, Niger Delta, Nigeria. J Aquac Res Development 6: 350. doi:10.4172/2155-9546.1000350

Copyright: ( 2015 Owhonda KN. This is an open-access article distributed under the terms of the Creative Commons Attribution License, which permits unrestricted use, distribution, and reproduction in any medium, provided the original author and source are credited. 
Citation: Owhonda KN (2015) Wet Season Variations of some Physicochemical Parameters of the Brackish Water farm, Buguma, Niger Delta, Nigeria. J Aquac Res Development 6: 350. doi:10.4172/2155-9546.1000350

Page 2 of 4

\begin{tabular}{|l|c|c|}
\hline \multirow{2}{*}{ Parameter } & $\mathbf{2 0 1 1}$ & $\mathbf{2 0 1 2}$ \\
\cline { 2 - 3 } & Mean \pm S.E & Mean \pm S.E \\
\hline $\mathrm{pH}$ & $6.8 \pm 0.07$ & $6.8 \pm 0.07$ \\
\hline $\mathrm{NH}_{3}-\mathrm{N}_{2}(\mathrm{ppm})$ & $0.05 \pm 0.02$ & $0.039 \pm 0.02$ \\
\hline $\mathrm{NO}_{2}-\mathrm{N}_{2}(\mathrm{ppm})$ & $0.05 \pm 0.00$ & $0.05 \pm 0.00$ \\
\hline $\mathrm{NO}_{3}-\mathrm{N}_{2}(\mathrm{ppm})$ & $0.25 \pm 0.00$ & $0.25 \pm 0.00$ \\
\hline Alkalinity(ppm) & $59.14 \pm 3.33$ & $56.29 \pm 3.85$ \\
\hline $\mathrm{CO}_{2}(\mathrm{ppm})$ & $8.21 \pm 0.47$ & $7.29 \pm 0.53$ \\
\hline Salinity(ppt) & $14.79 \pm 1.27$ & $13.79 \pm 1.16$ \\
\hline D.O(ppm) & $4.93 \pm 0.17$ & $4.61 \pm 0.20$ \\
\hline Temperature $\left({ }^{\circ} \mathrm{C}\right)$ & $28.57 \pm 0.48$ & $27.79 \pm 0.40$ \\
\hline
\end{tabular}

Table 1: Summary of physicochemical variations for 2011 and 2012.

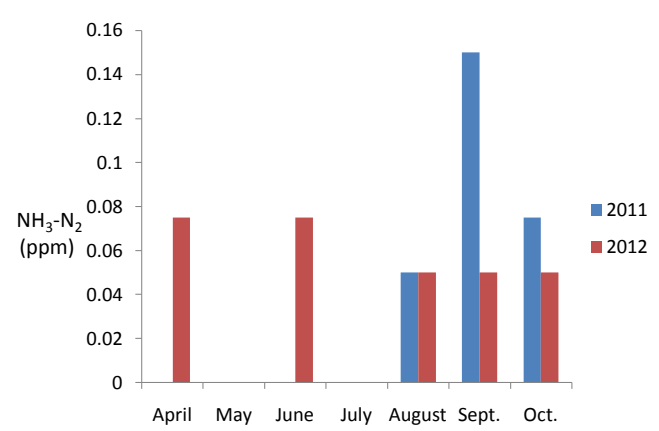

Figure 2: Ammonia-nitrogen variation for 2011 and 2012.

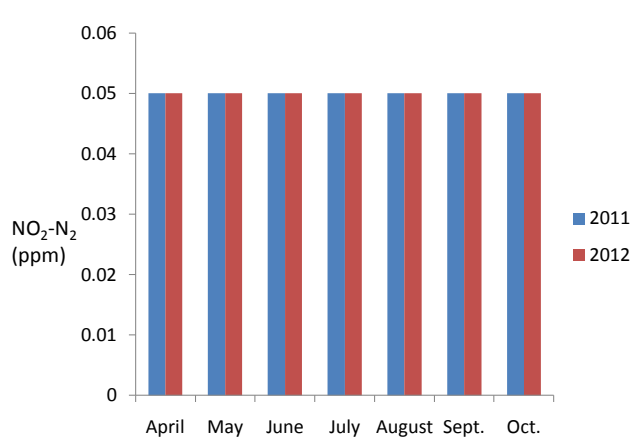

Figure 3: Nitrite-nitrogen variation for 2011 and 2012

Regional Aquaculture Centre (NIOMR/ARAC) brackish water fish farm; Buguma is located in Asaritoru Local Government Area of Rivers State; Nigeria. It is an example of a fish farm where tidal water flows in and out between the farm and adjoining creek; enhancing constant exchange of water.

\section{Materials and Methods}

\section{Study area}

This study was carried between April-October of 2011 and 2012 at the Nigerian Institute for Oceanography and Marine Research/ African Regional Aquaculture Centre (NIOMR/ARAC) brackish water fish farm; Buguma. This is the period of wet season in Nigeria. The Nigerian Institute for Oceanography and Marine Research/African Regional Aquaculture Centre (NIOMR/ARAC) brackish water fish farm; Buguma is located in Asaritoru Local Government Area of Rivers State; Nigeria. There are a total of 19 ponds with a main channel which is linked to Buguma creek via a main sluice gate (Figure 5). The ponds are naturally stocked with various species of shell and fin fishes from the wild. This brackish water fish farm is stocked with both fin and shell fish species including periwinkle; oyster; tilapia and mullet etc. The ponds are of different sizes. The smaller sized ponds for recruitment while the larger ones are for grow-out.

\section{Data collection and analysis}

Some Physicochemical parameters were monitored twice each month from April to October in 2011 and 2012; covering wet season for both years in the region and the average values of each parameter for the earthen ponds recorded. Salinity was monitored with Atago handheld refractometer s/mill-E; Cat No. 2442; the water surface temperature with thermometer while other parameters were monitored with Lamotte Salt Water Aquaculture Test kit; code 3635-03. Parameters monitored include $\mathrm{pH}$; ammonia-nitrogen $\left(\mathrm{NH}_{3}-\mathrm{N}_{2}\right)$; nitrite-nitrogen $\left(\mathrm{NO}_{2}-\mathrm{N}_{2}\right)$; nitrate-nitrogen $\left(\mathrm{NO}_{3}-\mathrm{N}_{2}\right)$; alkalinity $\left(\mathrm{CaCO}_{3}\right) ; \mathrm{CO}_{2}$; salinity; dissolved oxygen (D.O) and water surface temperature.

\section{Results}

The result obtained indicates that for 2011 average values of $\mathrm{pH}$ were between 6.5-7; ammonia-nitrogen 0-0.1 ppm; nitrite-nitrogen 0.05-0.05 ppm; nitrate-nitrogen $0.25-0.25 \mathrm{ppm}$; alkalinity $40-80 \mathrm{ppm}$; carbon (iv) oxide 5-10 ppm; salinity 9-20 ppt; dissolved oxygen 3.8$6 \mathrm{ppm}$; and temperature ranges were $26-31^{\circ} \mathrm{C}$ while for 2012 average values for $\mathrm{pH}$ were between 6.5-7; ammonia-nitrogen 0.0-0.1 ppm; nitrite-nitrogen $0.05-0.05 \mathrm{ppm}$; nitrate-nitrogen $0.05-0.25 \mathrm{ppm}$; alkalinity 40-80 ppm; carbon(iv) oxide 5-10 ppm; salinity 9-20 ppt; dissolved oxygen 3.8-5.6 ppm and temperature $26-31^{\circ} \mathrm{C}$ (Figure 6). There were no significant differences $(\mathrm{p}>0.05)$ in the parameters for both years. The values for each parameter were within the tolerable limits for aquaculture but where not necessarily optimum. For example; the expected range of $\mathrm{pH}$ for optimum aquaculture is usually

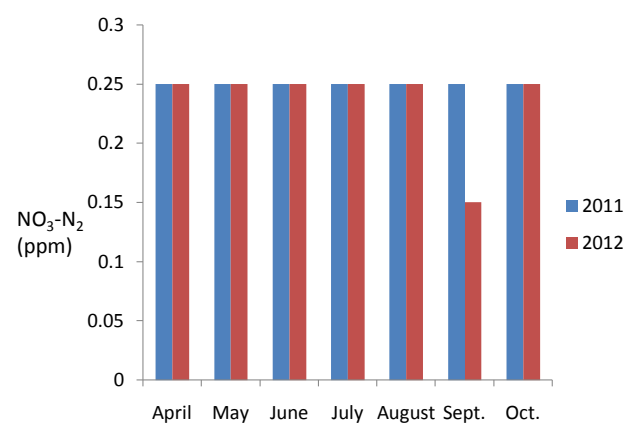

Figure 4: Nitrate-nitrogen variation for 2011 and 2012.

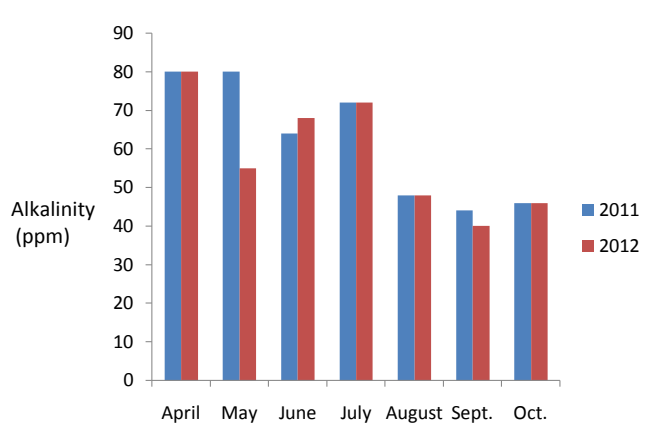

Figure 5: Alkalinity $\left(\mathrm{CaCO}_{3}\right)$ variation for 2011 and 2012. 
Citation: Owhonda KN (2015) Wet Season Variations of some Physicochemical Parameters of the Brackish Water farm, Buguma, Niger Delta, Nigeria. J Aquac Res Development 6: 350. doi:10.4172/2155-9546.1000350

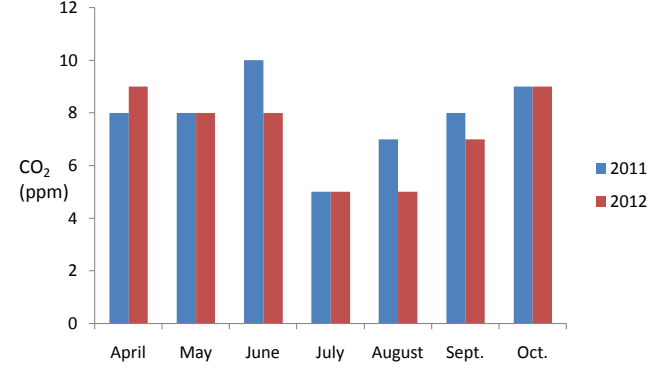

Figure 6: Carbon (IV) oxide $\left(\mathrm{CO}_{2}\right)$ variation for 2011 and 2012.

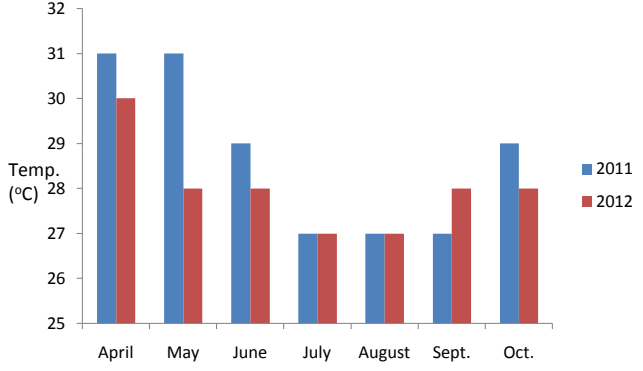

Figure 9: Temperature variation for 2011 and 2012.

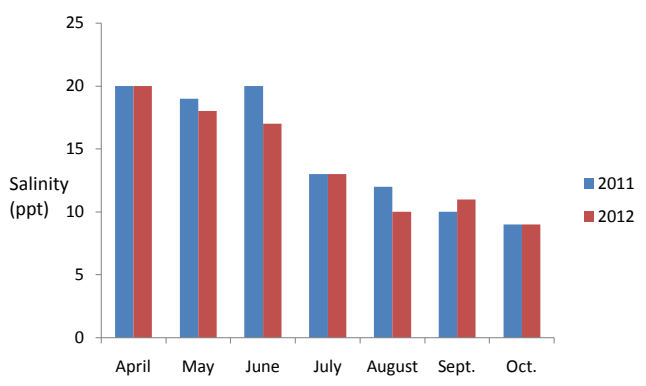

Figure 7: Salinity variation for 2011 and 2012.

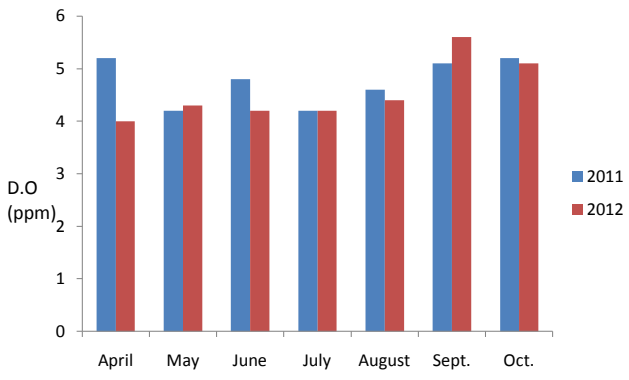

Figure 8: Dissolved oxygen variation for 2011 and 2012.

within 6.5-8.5 and the $\mathrm{pH}$ range obtained coincides with this. On the other hand; the optimum value for dissolved oxygen is usually above 5 ppm but the values obtained showed a lower average value of $3.8 \mathrm{ppm}$.

\section{Discussions}

Organisms in aquatic systems usually survive and thrive within certain limits of physicochemical parameters. Outside such limits they experience disease and eventual death. Variations were observed in the physicochemical parameters for this season for both 2011 and 2012 (Figure 7). However; when compared using statistics there were no significant differences $(p>0.05)$ for all parameters between the years for this season. Water levels fluctuated for the season and for both years. This may be attributed to rainfall and tidal movement [15].

Physicochemical parameters like $\mathrm{pH}$; ammonia-nitrogen; nitritenitrogen and nitrate-nitrogen did not show marked fluctuations. In most cases they remained the same. Even when they fluctuated it was for ranges within tolerable limits [16]. This is may be attributed to adequate buffering of the pond resisting these changes. Other parameters like salinity; alkalinity; $\mathrm{CO}_{2}$; D.O and temperature hard identical fluctuation ranges for both years in this season. However; salinity had a steady decrease from April to October in both years. Since April is just the beginning of wet season (rainfall) this steady decrease in salinity may be attributed to a gradual decrease in the concentration of ions as rainfall increased within the year. This observation is in agreement with the findings of Ikusemiju [17] in Lagos lagoon; DublinGreen [8] in Bonny River; Ekeh and Sikoki [18] in the New Calabar River and Francis et al. [12] in Andoni River system (Figure 8).

The range for dissolved oxygen was identical with those of Erondu and Chinda [11] while temperature was identical with those of DublinGreen [8] and Ezenwa et al. [19]. The fluctuation can be attributed to increase in sunlight which enhanced photosynthesis and thus; dissolved oxygen (Figure 9).

\section{Conclusion}

Sustainable fish production depends on environmental conditions. Thus; to increase fish production in riverine communities and decide the fish species to culture monitoring of water quality is indispensable. Therefore; proper management of these parameters will contribute immensely to fish production and enhance experiments seeking to adapt fish species to this region in the Niger Delta when tolerable limits has been established.

\section{References}

1. Adebisi AA (1981) The physicochemical hydrology of a tropical seasonal riverupper Ogun River. Hydrology 2: 157-165.

2. Ayodele I, Ajani EK (1999) Essentials of fish farming aquaculture.

3. Adeogun OA, Fafioye OO, Olaleye GO (2005) The relationship between some physicochemical parameters and plankton composition on fish production in ponds.

4. Wade JW, Stirling HP (1999) Fertilization of earthen ponds; effects on physicochemical characteristics and eutrophication of pond water soil. J Aquatic Sci 14: 5-12

5. Harney NV, Dhamani AA, Andrew RJ (2013) Seasonal Variations In The Physicochemical Parameters Of Pindavani Pond of Central India

6. Owhonda NK, Akinrotimi OA, Ansa EJ, Edun OM, Anyanwu PE, et al. (2007) Wet Season variations in physicochemical parameters of brackish water fish ponds and main channel in Buguma, River state, Nigeria. Journal of Fish International 2: 255-259.

7. Shind SE, Pathan TS, Raut KS, Sonawane DL (2011) Studies on physicochemical parameters and correlation coefficient of Harsool-savangi Dam, District Aurangabad, India. Middle-East Journal of Scientific Research 8: 544554.

8. Dublin-Green CO (1990) Seasonal and Spatial variations in some physicochemical parameters of the Bonny River (Niger Delta).

9. Yoloye V (1976) The ecology of the bloody cockle Anadara (Senilia senilis (L.) Bull. 
Citation: Owhonda KN (2015) Wet Season Variations of some Physicochemical Parameters of the Brackish Water farm, Buguma, Niger Delta, Nigeria. J Aquac Res Development 6: 350. doi:10.4172/2155-9546.1000350

10. Yakubu AF, Sikoki FD, Horsfall M (1998) An investigation into the physicochemical conditions and plankton organisms of the lower reaches of the Nun River, Nigeria. Applied Sci Env Manag 1: 38-41.

11. Erondu ES, Chindah AC (1991) Variation in the physicochemical features and phytoplankton of the New Calabar River at Aluu, Rivers State, Nigeria.

12. Francis A, Sikoki FD, Ansa EJ (2007) Physicochemical parameters of the Andoni River system-Niger Delta, Nigeria. Journal of Fish International 2: 27-31.

13. Nag A, Gupta H (2014) Physicochemical analysis of some water ponds in and around Santiniketan; West Bengal, India. Int J Environmental Sciences 4: 676-682.

14. Nwadukwe FO, Onuoha GC (2004) Day time variations in temperature; dissolved oxygen and $\mathrm{pH}$ in brood catfish ponds. Journal of Applied Zoology and Environmental Biology 6: 71-75
15. Ikusima I, Lim RP, Furtuso Jl (1982) Environmental conditions. In: Futado $\mathrm{JI}$, Mori S (eds.). The Ecology of a tropical fresh water swamp, Tasek Bera Netherlands.

16. Boyd CE (1992) Water quality management in pond fish culture. Elsevier Science Co. New York.

17. Ikusemiju K (1973) A study of the catfish of Lekki Lagoon, with particular reference to the species Chrysichthys walker (B). PhD thesis. University of Lagos, Nigeria.

18. Ekeh LB, Sikoki FD (2003) The state and seasonal variability in some physicochemical parameters of the New Calabar River. Nigeria. Supplemta ad Acta Hydrobiology 5: 45-60.

19. Ezenwa BI, Alegbeleye WO, Anyanwu PE, Uzoukwu PU (1990) Cultivable fish A Research Survey Second Phase 1986-1989. 